\title{
BETWEEN LEGAL NORMS AND GEOPOLITICAL IMPLICATIONS: ADMISSION OF KOSOVO TO THE UNITED NATIONS?
}

\author{
Bekim BALIQI \\ Professor, Department of Political Science, University of Prishtina, Kosovo \\ E-mail: bekim.baliqi@uni-pr.edu
}

\begin{abstract}
One of the basic attributes of statehood apart from the territory, population, and government is international recognition, which defines the capacity of states to enter into relations with other states. Through a comparative method, the main goal of the current research is to analyse the foreign policy of Kosovo as a case study and compare the admission processes of Israel and East Timor, countries with significant similarities to Kosovo's situation and geopolitical context. By analysing the principles of international law concerning state recognition, this research article explores the conditions and policies that could lead Kosovo to be admitted to key international organizations, and particularly to the United Nations. What significance does membership in the United Nations have for the sovereignty and international legitimacy of states, and what is Kosovo's foreign policy approach to prospective admission to the UN? These are the two central research questions, which lead this research analysis. The research assumes that the process of international recognition and membership in international organizations can be accomplished through a better foreign policy strategy and a smart proactive diplomacy. This can be done initially through admission in the UN specialized agencies and the dissemination of fulfilment of normative criteria such as commitment to peace, democracy and respect for human rights and minorities, principles that are crucial in recognizing new states. Through the findings and recommendations, the research aims to contribute to the understanding of foreign policy approaches toward membership in the international organizations, particularly admission of the new states to the United Nations.
\end{abstract}

Key words: Foreign policy, United Nations, membership, international recognition, Kosovo. 


\section{Introduction}

The political conditions in Southeast-Europe in recent years have been characterized by uncertainty in diverse areas, including a severe economic situation, vague foreign relations among neighbour states and unusual behaviours of political leaders. In this context, Kosovo has experienced several governmental, socio-economic and political crises. Therefore, its recent foreign policy, as a result of the domestic and regional political settings during this period, was not in a very favourable position. In Kosovo's past, its key foreign policy objective and national interest could be defined by the phrase "persuasion of the world opinion". Currently, that phrase can be replaced with the more attractive term "lobbying", which is aimed at international recognition as an independent state. In both situations, consolidation of the foreign policy is not perceived as a crucial sector to the affirmation of national interests in the international system of sovereign actors. The foreign policy thus is an integral part of the overall national interests, but its reduction to the welcoming of foreign diplomats and lobbying activities ignores the right advance of the capacities, strategies, and diplomatic engagement to achieve the fundamental foreign policy intentions.

Apart from the territory, population, and government, one of the basic attributes of statehood is international recognition, which defines the capacity of states to enter into relations with other states. States can be recognized individually by other countries establishing bilateral relations, which is known de jure as diplomatic recognition, but also collectively through admission to international organizations, as is the case with the United Nations (Peterson, 1997). The fact that, after more than a decade of independence, the issue of Kosovo's recognition and the membership in the international organizations remains an uncompleted issue reveals the lack of ability of Kosovo's foreign policy. The main reason for the large non-recognition and non-admission is unfavourable geopolitical constellations, actually of the opponent position of Serbia, Russia, China and other powerful states. However, political and legal arguments in the favour of Kosovo's recognition and admission, as well as diplomatic and foreign policy potential are higher than they are been in the past.

Diplomatic recognition, or international recognition of the state, is the first step in achieving external legitimacy and sovereignty. While international recognition is crucial in the launching of the relations between states and the admission into the international arena, it is not the single or only element that states need to be legitimate and acknowledged member of the international system (Grant, 1999). Nevertheless, Kosovo remains a contested state essentially because it is still not a member state of the United Nations; subsequently, its international legitimacy is disputed. The process of recognition can be completed and the consolidation of statehood can be achieved only when Kosovo becomes a member state of the UN. Thus, Kosovo's foreign policy needs to create a more effective strategy and 
coordinate actions to ensure recognition and membership as soon as possible in international mechanisms, first and foremost in the most important world organizations, such as the United Nations (UN). Kosovo's admission to the UN would not only finalize its statehood but also strengthen its position in international relations. Given the attitudes of some powerful states towards Kosovo and their influence within the UN decision-making mechanisms, admission to that international body will certainly not be easy nor soon accomplished, but it is not impossible. This objective can be achieved through dynamic diplomatic actions, regional cooperation and more political engagement toward states that hesitate to recognize Kosovo and by reaching an agreement with Serbia within the "Brussels negotiations", would enable membership in the UN in a short time.

The article will first elaborate on the legal procedures and criteria for the admission of states to the UN. Afterwards, the admission processes of some "contested" states will be compared and discussed concerning their geopolitical circumstances and diplomatic actions. In the end, the findings will be summarized, and recommendations will be provided on how priorities can be established as well as to what measures and actions Kosovo's foreign policy should take to join the UN. The research will be based on comparative foreign policy as an essential analytical approach in international relations studies. Furthermore, this method is widely applied in various foreign policy studies (Smith, Hadfield, \& Dunne, 2012). By analysing the admission procedures and criteria as well as comparing the membership processes of states with similar legal and geopolitical circumstances to that of Kosovo, the research aims to highlight analogies and offer lessons learned from the elaborated case studies. These cases are certainly not identical and should not be entirely imitated but rather viewed as a model to design the most effective action strategy. Given that the recognition of states is primarily a political act, admission can also be regarded as the result of political bargaining and decisions. Thus, more than the principles of international law, the current research will analyse and address the political circumstances and activities that may lead to admission in international organizations, particularly the UN.

The question of the foreign policy of newly independent states poses a very interesting examination unit in the research field of foreign policy analysis (FPA) and more broadly into international relations. Based on a case study, but compared with other cases, research will take into consideration foreign policy convergence and divergence integrated into state strategies for recognition and membership in international organizations. Further, the research aims to contribute to the advancement of international recognition of new states as well as their membership in international organizations. Asking not only what are the motives and reasons that drive states to recognize or not recognize a new state, but also why states approve or prevent the admission of new states into the international organization, in this case into the United Nations. 


\section{Admission to the United Nations}

In addition to territory, population, and functional government, one of the key attributes for statehood is international recognition or the ability of states to enter into international relations with other states known also as the Montevideo Convention (Convention on Rights and Duties of States, 26 December 1933). This set of criteria is often acknowledged as a standard definition of statehood, which besides requirements of what constitutes a state, also explains that the existence of the state does not depend only and entirely on recognition by other states (Crawford, 2006). Nevertheless, the admission of the state into the international community happens only through recognition by other states, thus empowering states as a factual actor in the international arena and allowing a state to gain international legitimacy. This derives not purely based on legal criteria or international law but it is influenced also by political factors. As Peterson promptly expressed: "Three aspects of the international system have the greatest impact on the institution of recognition of governments: the competition among the great powers, the level of inter-state ideological conflict, and the extent of transnational interconnections among societies. (Peterson, 1997, p.6)

In practice, states can be recognized through the establishment of bilateral relations (i.e., diplomatic recognition by individual states) but also de facto through collective recognition by admission to international organizations, such as the UN. There are two main scholarly approaches to the issue of state recognition. The declaratory school of thought presumes that the recognition of the state should be a result of its actual existence. In other words, the de facto status of the state is a precondition for the de jure recognition from other states. Contrary to this approach, the constitutive school holds that statehood is considered to be completed only after the recognition from other states, which is a matter of legal judgement and political decisions (Grant, 1999). As many case studies investigated here reveal, state recognition and consequently the admission in the international organisations are not fully isolated from political support, primarily by the powerful states. The United Nations, established 75 years ago, is currently the most important international organization. It has an objective for universal membership and aims to cover most areas of international activity. However, membership is not entitled automatically to every applicant state nor unconditionally to every new member.

The essential questions raised in this regard are as follows: What is the significance of UN admission for the sovereignty of states, and how has Kosovo approached its foreign policy in its efforts at admission to the UN? The main assumption in this research is that the process of international recognition, consolidation of foreign policy, and the accomplishment of statehood can only be achieved when Kosovo becomes a regular member state of the UN. This foreign policy objective can be achieved through increased diplomatic engagement and better political argumentation toward states that hesitate to recognize Kosovo or support its membership in international organizations. 
Certainly, the decision to recognize a state depends primarily on the domestic circumstances and national interests, but one should not underestimate the potential of smart foreign policy to influence decision-makers and state actor's behaviours toward a more affirmative approach.

Because there is no single and universal definition of sovereignty in international politics, international relations are characterized by "anarchy"not in the sense of chaos, but in the sense of lacking a single and legitimate world government (Morgenthau, 2008). International relations are structured by various legal rules and norms, as well as institutions and organizations. The number of international organizations has grown steadily since the last century, and so their activities have become more important and disseminated. There are at least three types of international organizations in terms of their functionality. First, international organizations serve as a diplomatic and foreign policy tool or instrument of member states, or at least of the most powerful member states. Second, they act as an arena, a meeting point of interests, and a forum for intergovernmental compromises and negotiations, intending to bring those actors closer and resolve disputed issues or those of common interest. Finally, international organizations are described as the main actors in international relations, where states delegate powers and competencies through their state representatives, who create certain policies that are adopted and implemented by the relevant international organization (Rittberger \& Zangl, 2003).

Admission of states into the large family of nations, often referred to as the UN, is essential for the recognition of state sovereignty and the eligibility to develop relations with other states. However, membership in international organizations itself is not guaranteed to every candidate state because the process depends, on one hand, on meeting the accession criteria and, on the other hand, on the political will and interests of other members. In a very important study entitled "Recognition and the United Nations," professor of International Law John Dugard (1987) categorized state recognition into two essential trends: by the collectivization of recognition, achieved mostly through membership in important international organizations, and by strengthening normative criteria such as commitment to peace and respect for human rights and minorities, principles that are crucial in recognizing new states. In 1948, the International Court of Justice in 1948 developed an advisory opinion on the question of the criteria of the General Assembly of the UN concerning the admission of a new member state as to whether or not the criteria set in Article 4 (1) were exhaustive. The requisite conditions for membership in the United Nations are that an Applicant must 1) be a State; 2) be peace-loving; 3) accept the obligations of the Charter; 4) be able to carry out these obligations; and 5) be willing to do so (ICJ Reports 57, 1948). In other words, the ICJ reaffirmed that only the criteria set in Article 4 must be applicable for admission and "it ruled that rejecting admission on purely political grounds was impermissible." (Chesterman, Johnstone \& Malone, 2016, p. 199). 
Political attitudes and the predisposition of the influential states rather than legal procedures, however, are essential to the membership of a new state. Article 4 of the UN Charter regulates and defines the issue of admission of new members to this world organization, so they become legitimized as sovereign and internationally accepted states. In the early years of the UN, because of antagonistic political positions, the admission of the new members was a contentious issue. Since the late 1970s, there have only been a few contested cases of admission to the UN, such as Palestine and Taiwan (Chesterman, Johnstone \& Malone, 2016, p. 195-232). As Thomas Grant (2009) explained, membership involves two essential dimensions: the procedural mechanisms upon which applications are considered and the legal criteria to be met when considering an application. The basic criteria are included in the first paragraph of the fourth article, which states: "Membership in the United Nations shall be open to all peace-loving States, which accept the obligations contained in the present Charter and, in the judgment of the Organization, are able and willing to fulfil these obligations" (U.N. Charter art. 4, para. 1).

According to the second paragraph of this article, new members of the UN may become those "States" after formal application to the Secretary-General's office is proposed by the Security Council and approved by a two-thirds majority vote of the General Assembly. The essential issue of admission to the $\mathrm{UN}$, which is the main concern for successful membership of Kosovo, is getting all five permanent members to agree and at least nine of the 15 members of the Security Council to vote on such a recommendation (U.N. Charter art. 27, para. 3). In other words, without the Security Council's approval and recommendation, the application cannot even be voted on in the General Assembly and admission decision cannot be taken. Kosovo's admission to the UN is a challenge beyond legal considerations and meeting the admission criteria or in respecting international law requirements. Moreover, Kosovo's key challenge is geopolitical constellations in the present international system, specifically, the composition of the member states in the Security Council, in which in addition to the Russian Federation and China (with their veto power), and as well as other states have not recognized Kosovo. Therefore, the serious analysis regarding membership should take into account that even if two-thirds of the member states in the General Assembly vote for acceptance of a new state, this is insufficient if it is not recommended by the Security Council. On the other hand, the Security Council's proposal may be blocked by the veto of one of the permanent members or if it does not receive votes from the simple majority.

The Security Council's composition consists of not only permanent member states but also those replaced by rotation and has a direct impact on the decision-making and thus on the fate of Kosovo's admission to the UN. However, the main challenge lies in the position of two permanent member states with veto power, the Russian Federation and China, which have so far categorically opposed Kosovo's declaration of independence. Although their 
position on the recognition of Kosovo as a state has evolved since Kosovo's independence to become more resilient and compatible with realpolitik, it is difficult to expect a radical change in such a short time. In fact, since the Russian military invasion of Crimea, an official discourse has undergone significant changes. In this context Russian representatives often have declared that the recognition of Kosovo is not excluded if Pristina's dialogues with Belgrade to achieve a compromised settlement. The sharp Russian tones against the "violation of international law," as propagated in Kosovo's case, were silenced after they interfered in South Ossetia and Abkhazia. Despite its nonrecognition attitude, Moscow continues to have diplomatic representation in Pristina, though not at the embassy level. Its presence implies that official Pristina authorities are a reference point for Russia. Consequently, Russia's eventual abstention on the UN Security Council is not entirely impossible, but depends on its arrangement with Western states, especially with the USA, as well as on its geopolitical consensus on NATO and other issues. On the other hand, China, which vehemently opposed Kosovo's statehood by comparing it with the secession threat from the province of Tibet, has now realized that Kosovo is not Tibet, nor is China, ex-Yugoslavia. But China's position on Kosovo will largely depend on its economic and geostrategic interests, especially those concerning the European Union and the United States. In two cases, the fate of Kosovo's membership is related to the developments in the world order and the broad interests of global players.

The fact that Kosovo's independence resulted in no apparent clash between world powers and that the opinion of the International Court of Justice on the question of Kosovo's unilateral declaration of independence removed the dilemma of its legality, created channels of communication and space for Kosovar diplomacy with those states that oppose Kosovo's statehood as well. Although diplomatic recognition from these states can hardly be expected soon, moving from "opposing" attitudes to a likely "abstaining" position about Kosovo's admission should not be excluded completely. These inclinations might remain hypothetical if Kosovo's foreign policy does not act immediately and strongly in the unfinished diplomatic battle where Serbia is already extremely active and aggressive. Therefore, Kosovo's foreign policy should now focus more on admission to international organizations, namely specialized UN agencies and, ultimately, the UN itself, rather than on individual recognition by states. All relevant institutions should take necessary measures and coordinate properly, to take appropriate action for Kosovo's applications to these international agencies and institutions. Foreign policy should prioritize this issue without wasting time and energy on peripheral and non-essential issues. 


\section{Comparative case studies: Israel and East Timor}

Similarly, with the case of Kosovo's geopolitical importance for the SoutheastEurope region, both cases of the analysis represent significant geopolitical attractiveness and stability implications for respectively the region of the Middle East and Southeast Asia.

Israel declared independence on May 14, 1948, after an internal conflict with the Palestinians and the failure of an international peace mission of the UN (UNSCOP). UNSCOP's Plan and Resolution 181 proposed a two-state division: the Jewish portion holding $56 \%$ and the Arab holding $43 \%$ of the territory and Jerusalem to be placed under the supervision and administration of the UN as a corpus separatum. The Israeli state was recognized de facto by the US and de jure by the Soviet Union, but the war with its Arab neighbours escalated within days, leading to a conflict of a wide international range. This, however, did not stop Israel from applying to the UN in November of that year, an application that was unofficially supported by the Norwegian SecretaryGeneral Trygve Lie, who assisted the delegation with advice and contacts in its lobbying campaign for admission (Heian-Engdal, Jensehaugen \& Waage, 2013, p. 472-476).

One of the main concerns and objections of Israel's admission to the UN at that time was the issue of peace, with the key question being: Should a state join the UN without having peace within its borders? Israel's foreign policy response was based on three main arguments: peace, equality, and credibility of the UN. Therefore, the Israel delegation that strongly lobbied for admission emphasized that UN membership would be a factor of stability and this would help find a solution to the conflict; that admission would enable Israel's equality vis-à-vis the negotiating party to reach a peace deal; and, third, that the UN with the principle of universalism would lose the prestige and credibility of inclusion and equal treatment of all nations in the event of Israel's rejection. Despite the campaign and support from two superpowers, on December 15, 1948, the request for Israeli membership was not approved by the Security Council after objections, especially by the UK and France, with five votes in favour, five abstentions, and one vote against accession from Syria's representative. However, despite this, Israel did not give up reapplied for membership on February 24, 1949. This time it was far more cautious in securing the votes of new members in the Security Council and ensuring that none of the permanent members would use a veto. Meanwhile, it made sure to demonstrate the peace agreement with Egypt as evidence of its peace-loving commitment and that diplomatic pressure on Britain and France was on its side this time. Following the approval of the Security Council, the request was recommended to the Assembly with 37 votes in favour, 12 rejections, and one abstained vote. On May 11, 1949, Israel was declared as the 59th member of the UN (HeianEngdal, Jensehaugen \& Waage, 2013, p. 479). 
The advantages of Israel's membership compared to Kosovo's efforts were, among other factors, that Israel was more successful in receiving political acknowledgement of the Holocaust and the crimes against Jews after World War II than Kosovo benefitted diplomatically in exposing the war crimes and damages caused by Serbia. Also, the number of UN members at that time was much smaller, and Israel, at the beginning of the Cold War, succeeded in gaining the recognition and support of the two superpowers that linked their friendly states' membership with support for Israel's accession to the UN. Of course, foreign policy and Israeli diplomacy also played a key role in these and other factors; for instance, it acted wisely and strategically in achieving these objectives, something which cannot be said of Kosovo's foreign policy.

East Timor, on the other hand, is an interesting parallel and a very similar case study to that of Kosovo. On June 10, 1999, the Security Council adopted a resolution establishing the mandate of the UN Mission in Kosovo (UNMIK) to carry out the duties of the legislature, the executive, and the judiciary. Only a few months later, a similar mission followed in East Timor (UNTAET), which took over all legislative, judiciary and executive power, with which to administrate. However, compared to Kosovo, East Timor (Timor-Leste) became independent in May 2002 and in September of that year became the 191st member of the UN. The statehood of East Timor might be interpreted as a postponed process of decolonization and self-determination. Because there were no significant disputes with Indonesia, which was independent and because East Timor also had support from neighbouring countries, especially Australia, UN membership was not contested, as the UN would continue with other missions to be present and assist in state-building. However, East Timor's membership in the ASEAN (Association of Southeast Asian Nations) was a bit trickier, and freezing of relations with Australia and to some extent with Indonesia prompted its foreign policy to forge closer bilateral relations with other countries, especially China (Sahin, 2014, p.6). Despite formal recognition and full membership in the UN, at the G77, also known as the Organization of Non-Aligned Countries and other UN agencies, the normative elements of recognition - elaborated upon by Dugard, the stability and functionality of the state, have seriously weakened the position and influence of this small country in the international arena.

East Timor, relating to its admission to the UN, had the advantage that its independence from Indonesia was not contested and its state-building was supported by the UN's mission, with no open objections from any member of the Security Council and the General Assembly. More than the merit of its foreign policy and diplomacy, it was the formal fulfilment of the application criteria that enabled East Timor to become a member of this international organization. Certainly, the abovementioned cases have many differences compared to that of Kosovo, both in historical and political contexts and in the power constellation in the international arena. But the lessons that Kosovo can 
draw from these and other similar cases can undoubtedly help in obtaining admission to international organizations.

\section{Admissions of the former Yugoslav Republics to the UN}

Following the dissolution of the Socialist Federal Republic of Yugoslavia, the seceding republics received widespread international recognition from other states, including members of the United Nations. Almost a year after the declaration of Independence on 18 May 1992, the Security Council recommended Slovenia's admission to the UN. On 22 May 1992, the General Assembly admitted Slovenia, Croatia and Bosnia and Herzegovina to the United Nations as member states. Whereas the Macedonian case of admission to the UN was delayed and more complicated due to the dispute with Greece concerning of its state denomination. The UN Security Council recommended Macedonia's admission to the UN under the provisional name of the Former Yugoslav Republic of Macedonia (FYROM) on 7 April 1993 and on the following day, the General Assembly admitted FYROM to the UN (Grant, 2009). Following its application, Montenegro was admitted on 28 June 2006, becoming a 192nd member of the United Nations. Serbia joined the United Nations on 1 November 2000 as the Federal Republic of Yugoslavia and in June 2006, continued membership as the Republic of Serbia.

The post-Yugoslav area or more broadly the Southeast European region represents an area of turbulent past and different challenges, beginning with diverse and often contested identities, various geopolitical intentions and foreign policy goals. The NATO membership of Slovenia, Croatia, Albania, North Macedonia and Montenegro as well as the EU membership of Greece, Slovenia and Croatia constitutes a security bond and geopolitical area that is western-oriented (Keil \& Stahl, 2014). However, the equivocal foreign policy of Serbia followed with its undecided orientation toward the EU, NATO and its close ties with Russia and China destabilize the region with regards to prospective regional cooperation. Moreover, the animosity between Serbia and Kosovo has an impact not only on their respective foreign policy objectives but involves both regional and international supports for or against Kosovo's recognition and membership in the international organizations. Kosovo's admission to the UN represents a fundamental challenge to its foreign policy because its admission depends on not only on the number of states that recognize it as an independent state but also on the approval of the Security Council and the General Assembly members.

\section{Kosovo's Admission to the UN: Challenges and Opportunities}

Kosovo's Ministry of Foreign Affairs was established only after the independence, on 3 April 2008, when it began creating its diplomatic missions and services. The selection of the first ambassadors and their appointment was made through an open call and transparent process. However, the subsequent 
appointment of ambassadors and recruitment of the diplomatic staff is largely done through partisanship, nepotism and clientelism of the ruling parties (Demjaha, 2020, p.22-26). This caused considerable incompetence and inadequacy in the Ministry of Foreign Affairs and among its diplomatic services. Kosovo currently operates over thirty embassies and twenty consulate missions around the world, including two representation offices, one in Cairo, Egypt and another one in Belgrade, Serbia (Kosovo Embassies \& Consulates, n. d.). Kosovo is recognized by over 117 member states of the United Nations; Kosovo is a member state in more than twenty international organizations, such as the International Monetary Fund, World Bank, European Bank for Reconstruction and Development. Kosovo has signed numerous international agreements, such as a Stabilization and Association Agreement with the European Commission (Ministry of Foreign Affairs of the Republic of Kosovo, List of recognitions, n. d.). Despite these achievements in foreign relations, Kosovo's international legitimacy remains contested and its membership in the most important international organizations is disputed. The unsuccessful application to the United Nations Educational, Scientific and Cultural Organization (UNESCO) and International Police Organization (INTERPOL) were a clear illustration of diplomatic failure and ineffective foreign policy decision-making.

What are the main objectives of Kosovo's foreign policy and where do they originate from? One of the key goals of foreign policy is to secure sovereignty and territorial integrity, which, in addition to military, political, and economic means, might be achieved through the creation of alliances and membership in international organizations (Legg \& Morrison, 1991). Thus, one of the main objectives of Kosovo's foreign policy since the establishment of the Ministry of Foreign Affairs has been to accelerate international recognition and improve Kosovo's chances of admission to international organizations (Krasniqi, 2014, p.204). Even after more than ten years, those goals are still largely unfulfilled, particularly the membership in international organizations. The crucial issue in Kosovo, as a case study, is analysing what the core obstacles are and how they can be overcome. As described above, a veto from a permanent member state of the Security Council, such as Russia and China, can prevent Kosovo's request and eventual recommendation for admission to the General Assembly. As Thomas Grant plainly explained:

A candidature for the admission of Kosovo, following the unilateral declaration of independence, would in all likelihood attract a Security Council veto, assuming that the matter reached the Council. The priority question would be whether such an application would be sent to the Council at all. (Grant, 2009, p.186-187)

Kosovo's foreign policy should aim to consolidate its statehood internationally by acting at the same time in many dimensions and directions, obtaining recognition and demanding membership in different international organizations. Its failures to obtain membership in UNESCO and INTERPOL 
would need to be analysed carefully for other and subsequent applications to succeed. This can be achieved by working simultaneously through diplomatic, economic, cultural, and other viable channels. Strong and compelling arguments need to be presented to gain support, especially for membership in important international organizations. In orders to be present at such forums, Kosovo's diplomacy must strengthen support from many countries for admission in specialized UN agencies. In coordination with its allies and with a proper action plan, Kosovo's foreign policy position would be strengthened by growing recognition as well as by joining international institutions. In doing so, UN membership would no longer be impossible.

While the epilogue of the negotiations with Serbia remains an open question, opportunities for recognition and Kosovo's UN membership are almost deadlocked; but this in no way means that its foreign policy must be passive. On the contrary, Kosovo's diplomacy should be much more active and persistent in strengthening sovereignty by working on collective recognition. It can do so through pursuing membership in other international organizations with the purpose to create favourable conditions for its admission to the UN as an independent state. The cases of Israel and East Timor show that neither disputes with other countries nor size, nor military and economic power are decisive in this endeavour. Determinant in this regard is the role and impact of foreign policy through wise and strategic actions. Although Kosovo meets both the formal and the normative criteria required for admission, the part of political argumentation and diplomatic persuasion remains crucial in achieving membership in international organizations. Its foreign policy should be focused both on establishing bilateral relations with states that do not recognize Kosovo and on strengthening multilateral activities at international summits, forums, and organizations. These two areas of action are complimentary, so there is no success in multilateral relations without bilateral improvement and vice versa.

Just as integration into the European Union and membership in NATO are of national interest for Kosovo, admission to the UN must be a major priority of foreign policy. In an increasingly changing geopolitical configuration, Kosovo cannot afford to wait indefinitely, nor to be passive in foreign policy. The increasing influence of Russia, China, and other important countries in the region must be taken seriously and should encourage Kosovo to act more effectively in gaining admission in international organizations. The positions toward Kosovo's recognition of the opponent states, however, are unlikely to change until there is a legally binding peace agreement between Kosovo and Serbia. Other steps the Kosovo government should take to obtain UN membership are to initiate a termination of the UNMIK mission and thereby invalidate Resolution 1244, which is commonly invoked by Serbia as an impediment to sovereign recognition (Krasniqi, 2014). Kosovo can also set forth the arguments that it fully respects minority rights; has a stable security situation; a commitment to dialogue that resolves disputes; and commitments to peace that make the UN mission unnecessary. Of course, these, as well as 
other actions must be in coordination with its allied states. In particular, selecting appropriate timing and gaining support from reluctant members should be made with increased caution during the membership application process. For this and other strategies, the Ministry of Foreign Affairs should cooperate with both international state actors and research institutes, in addition to local and international academics and experts. The Ministry of Foreign Affairs has a Department for International Organizations (MFA-DIO), its job description emphasizing the following:

Develops close relationships with Kosovo universities and other higher education institutions, as well as with relevant Kosovo academies, to create experiences with MFA good practices on specific issues, in particular, the advancement of presentation in international organizations. (Ministry of Foreign Affairs of the Republic of Kosovo, Department of International Organizations, n. d.).

From my own experience working for many years in the Department of Political Science at the University of Pristina, I do not remember anyone from the MFA creating close relationships with academic staff concerning presenting ideas about and joining international organizations. Even in the rare foreign policy discussions organized mostly by the civil society organizations, neither I nor any of my colleagues who are international relations scholars were invited to discuss or even consult on these topics. Similar to the above description, the government's strategy for full international recognition of the Republic of Kosovo in June 2011 remains merely formal (Krasniqi, 2014; Demjaha, 2020).

As the dialogue between Pristina and Belgrade has wasted valuable time and energy without bringing proper results, any further waiting can bring only irreparable damage to the position of Kosovo and endanger the country's international legitimacy and subjectivity. Activating the potential of foreign policy requires the consolidation of domestic policy as well. In other words, Kosovo's struggles in the consolidation of statehood, as much as it requires more coordination and action toward negotiations with Serbia, involves diplomatic and political activities to be conducted internationally. Membership in international organizations, especially in the $\mathrm{UN}$, is crucial in attaining international legitimacy and consolidating sovereignty. With increasing global dynamism, it is no longer just a matter of desire to become part of international structures but an imperative to protect and promote its interests and values.

\section{Conclusion}

There is no specific rule or formula for states to be recognized internationally or to join international organizations. Moreover, legal norms, acts of international law, and other normative criteria are usually premises, not assurances, in admitting new states to international institutions. As discussed above, the geopolitical and geostrategic interests of the world powers and the individual state approaches in foreign policy are decisive factors in the 
membership in the international organizations. In the first year of its independence, with the strong support of the United States and other Western countries, Kosovo has attained more than 50 recognitions and joined two very important organizations of the UN system, the World Bank and the International Monetary Fund. However, momentum had been lost regarding gaining more recognition and admission in international organizations even after the decision of advisory opinion from the International Court of Justice in 2010, which declared that Kosovo declaration of independence does not violate international law. The main reason for the non-admission is unfavourable geopolitical constellations, coming as a result strong position Russia, China and other powerful states hold against membership. However, political, ethical and legal arguments in the favour of Kosovo's recognition and admission in the international organizations, as well as diplomatic potential are greater now than ever before.

The history of individual states' membership in the UN reveals that each case had its specificities connected to the historical and political contexts of the time. However, the comparison with the examples mentioned above shows that the Kosovo case is also specific and quite complex as its effort to obtain admission is related to the interests of two veto powers, Russia and China, as well as other states with domestic concerns regarding secessions. Also, Serbia's ongoing campaign and propaganda against the recognition of Kosovo has had a profound effect on the attitudes of states that have not recognized Kosovo. It can be compared to the case of Israel, which, at the time of applying for UN membership, was in armed conflict with Arab countries and contested by all neighbouring countries. The situation in Kosovo is peaceful, with no significant inter-ethnic tensions; has been recognized by most of the neighbouring countries; and has constitutions and democratic institutions. What principally distinguishes the two cases, however, is the de facto support of Israel from both superpowers of that time and the ability of Israeli diplomacy to persuade other states to approve its membership application, despite much hesitation.

Compared to East Timor, which, like Kosovo, was under international administration, the post-independence security and political situation were tense with frequent turmoil, economic dependence, and neighbouring countries' reluctance to pursue its policies. But even in this case, gaining support from the UN and Asian states, including China, had a positive impact on international recognition and UN membership. More than the merit of its foreign policy was the conviction of delayed decolonization that enabled this small, peaceful country to be recognized by the member states and join the UN. The argument of decolonization in the case of Kosovo is not very convincing, as the breakup of Yugoslavia itself, the war in Kosovo, and NATO intervention disprove this claim. However, the UN's administration of Kosovo and the possibility that the mandate of this mission could de jure be concluded in the Security Council could be drawn as a proper parallel to the admission of East Timor. 
With its statehood, consolidated peace, acceptance, willingness and ability to carry obligations that come out of the United Nations charter, Kosovo fulfils all required criteria of Article 4. However, Kosovo should develop further arguments and campaigns based on the experiences, important facts and actions of other cases when developing a strategy for admission to the UN. But, politics in Kosovo primarily need to build the capacity and empower the right actors to develop much more effective strategies in its efforts to join international organizations. This should not serve as daily political rhetoric but as an immediate need to affirm state interests. The foreign policy of new states, more than recognition by individual states, must be focused on membership in international organizations, particularly in the UN and its specialized agencies.

\section{Bibliography}

Annan, K. (2000). We the peoples. The role of the United Nations in the 21st century. New York: United Nations.

Convention on Rights and Duties of States. (1933). Retrieved from http://avalon.law.yale.edu/20th_century/intam03.asp (22 January 2021)

Crawford, J. (2006). The creation of states in international law (2nd ed.). New York, NY, USA: Oxford University Press.

Chesterman, S. (2004). You, the people: The United Nations, transitional administration, and state-building. Oxford: Oxford University Press.

Chesterman, S., Johnstone, I., \& Malone, D. (2016). Law and practice of the United Nations: documents and commentary. Oxford: Oxford University Press.

Dugard, J. (1987). Recognition and the United Nations. Cambridge: Grotius Publications.

Grant, D. Th. (1999). The recognition of states: Law and practice in debate and evolution. Westport: Praeger.

Grant, D. Th. (2009). Admission to the United Nations: Charter Article 4 and the rise of the universal organization. Leiden: Martinus Nijhoff Publishers.

Heian-Engdal, M., Jensehaugen, J., \& Waage, H. H. (2013). Finishing the enterprise: Israel's admission to the United Nations. The International History Review, 35(3), 465-485.

International Court of Justice Reports 57, 1948. Retrieved from https://www.icj-cij.org/public/files/case-related/3/003-19480528-

ADV-01-00-EN.pdf (02 June 2021)

Keil, S., \& Stahl, B. (Eds.). (2014). The foreign policies of post-Yugoslav states. London: Palgrave Macmillan.

Kosovo Embassies \& Consulates, n. d., Retrieved from https://www.embassypages.com/kosovo (21 March 2020)

Krasniqi, G. (2014). Foreign policy as a constitutive element of statehood and statehood prerogative: The case of Kosovo. In S. Keil \& B. Stahl (Eds.), 
The foreign policies of post-Yugoslav states (pp. 198-220). London: Palgrave Macmillan.

Legg, K. R., \& Morrison, J. F. (1991). The formulation of foreign policy objectives. In R. Little \&M. Smith (Eds.), Perspectives on World Politics, (pp.59-68.) London: Routledge.

Morgenthau, H. (2008). Politika ndërmjet kombeve-Lufta për pushtet dhe paqe. [Politics among Nations- The struggle for power and peace]. Tiranë: Plejada.

Ministry of Foreign Affairs of the Republic of Kosovo, Department of International Organizations, Prishtina. Retrieved from http://www.mfa-ks.net/en/ministria/535/departamenti-pr-organizatandrkombtare/535 (21 January 2021)

Ministry of Foreign Affairs of the Republic of Kosovo, List of recognitions, Retrieved from https://www.mfa-ks.net/politika/484/lista-enjohjeve/484 (20 April 2021)

Peterson, M. J. (1997) Recognition of governments: legal doctrine and state practice, 1815-1995, Basingstoke, Palgrave Macmillan.

Rittberger, V., \& Zangl, B. (2003). Internationale Organisationen-Politik und Geschichte, (3.Aufl.). [International Organization- Politics and History, ( $3^{\text {rd }}$ edition)]. Opladen: Springer Verlag.

Sahin, S. B. (2014). Timor-Leste's foreign policy: Securing state identity in the post-independence period. Journal of Current Southeast Asian Affairs, 33(2), 3-25.

Smith, S., Hadfield, A., \& Dunne, T. (Eds.). (2012). Foreign policy: Theories, Actors, Cases (2nd ed.). Oxford University Press.

United Nations (1945). Charter of the United Nations. Retrieved from https://www.un.org/en/about-us/un-charter (06 June 2021) 